\title{
Troubling Stories of the End of Occupy: Feminist Narratives of Betrayal at Occupy Glasgow
}

\section{Introduction}

In the autumn of 2011, the Occupy movement blazed across the political firmament, a mass expression of anger against the financial organisations at the heart of the recession in the United States and beyond, against wider economic and political inequalities, and against neoliberal, 'austerity' policy responses. Inspired by the slogan 'We are the $99 \%$ ', thousands bedded into public squares and parks in countries across the world. Yet most Occupy camps were short-lived, closing by the end of the year. The reasons for camp closure are deserving of more scholarly attention than they have thus far received, in part because they have important implications for future mobilization against neoliberal capitalism and austerity.

This article focuses on activist narratives about the end of Occupy. The years since the camps have seen the rise of an account in which closure is the result of external forces. Found in sympathetic media commentary (e.g., Graeber, 2013, pp. 271-273; Ennis, 2014; Penny, 2016) and academic/activist crossover literature (e.g., Manilov, 2013; Castells, 2015, pp. 191-201; Piven, 2014), this narrative emphasises the role of hostile governments and the police, as well as of structural issues like bad weather and homelessness, thus leaving the camps themselves unproblematised and facilitating a positive view of their legacy in the form of myriad spin-off campaigns. On this view, ' $[t]$ he challenge is to use the fertile ground left by the transformed earth to foster a multitude of new growth' (Hogue, 2012). Such a story of the end of Occupy is contested, however, by rival narratives depicting camps as heavily compromised by internal problems and as leaving a mixed or negligible legacy. Marxist and liberal formulations focus on the perceived inadequacies of horizontal decision-making (e.g., Roberts, 2012; Gitlin, 2013), while others more disposed to anarchist modes of organising root internal problems rather in the reproduction of pre-existing social inequalities (e.g., Halvorsen, 2012, p. 429). One of the most developed articulations of the latter is the feminist critique I seek to explore and augment here.

Published accounts from feminist participants in Occupy draw attention to internal problems, including the privileging of white, cis, male voices and experiences in camps and online (e.g., Maharawal, 2011; Pollitt, 2012), the platform given to openly sexist and racist discourses (e.g., Doyle, 2011), and incidences of harassment and sexual violence (e.g., Hardikar, 2012; McKeown, 2011). In response, feminists and their allies instituted safer spaces policies, caucuses of oppressed groups, 'progressive stacks' at general meetings, and feminist assemblies and online interventions (e.g., Maharawal, 2011; Selzer, 2011; Borthwick, 2014). The success of such measures in some contexts allows for a positive story of the end of Occupy akin to the first narrative above, in which creative connections between feminism and other left-wing groups have been revitalised (Borthwick, 2014; Talcott and Collins, 2012). In other camps, however, feminists became disillusioned: 'I gave up any hope we could sort this ... If the first few weeks were the honeymoon period, this was the bitter end of a relationship going badly wrong' (Anonymous, 2012, p. 444; also McAlpine, 2011). ${ }^{1}$ This is a story in which camps self-destructed for internal reasons, leaving little behind.

In what follows, I develop this feminist critique through a narrative analysis of interviews with activists from Occupy Glasgow. I show that most interviewees characterise the trajectory of the camp as a tragedy, all attribute responsibility for the camp's demise to co-campers and sometimes to themselves, and all present the outcome of Occupy Glasgow as limited, and in some cases even traumatic. Thus this case study poses a serious challenge to the more positive story of the end of 
Occupy and its legacy in activist circles. It adds depth to our understanding of the character, extent and impact of gendered inequalities in Occupy, and points to ways to develop the theorization of movement demobilization more generally. The argument is constructed in three parts. The first examines academic theorization of why movements end, in general, and why Occupy ended, in particular, suggesting both might profitably make use of the 'narrative turn'. The second deals with methodological considerations, discussing my dataset and my feminist and narrative approach, before I turn in the third to the plot, protagonists and denouement of interviewee narratives about Occupy in Glasgow.

\section{Literature Review: Theorizing the End of Movements}

In the field of social movement studies, the question of why movements end has received attention only recently (Davenport, 2015; Roth, 2017). As Davenport claims, in one of the few studies of what he calls social movement 'death':

the existing literature has been generally concerned with movement emergence and variations in the conduct of challengers once they are underway. Newer work has explored the outcomes of SMOs, but essentially little to nothing exists on the topic of the processes of exactly how social movement organizations demobilize (i.e. how they die)' $(2015$, p. 299).

Academic research into Occupy largely conforms to Davenport's view. There is substantial work on why and how the camps began (e.g., Roth et al., 2014; Kriesi, 2016), increasingly integrated into discussion of the emergence of a wider 'global wave' or 'cycle' of uprisings, or a 'movement of squares', 2011-14 (e.g.. Castells, 2015; Flesher Fominaya, 2017). In addition, considerable research has been conducted into the political characteristics and tactics of the 2011 camps (e.g., Halvorsen, 2015; Sotirakopoulos, 2016), and the interplay of online and offline interactions in either facilitating or constraining the capacity to mobilise around a shared collective identity (e.g., Kavada, 2015; Tufekci, 2017). Finally, there is some as-yet limited discussion of the outcomes of the camps. Flesher Fominaya (2017, pp. 12-14), for one, speculates that political outcomes of the wider wave include both state repression and the institutionalization of movement actors, and that there are significant biographical and cultural impacts still to be mapped (see also Bosi et al., 2016, p. 4; FernándezSavater et al., 2017). Some analytical inferences can be drawn from this literature as to the reasons for the end of Occupy (e.g., key players became 'burnt out' or integrated into governing bodies), but these are not explicitly theorised.

One exception is the small body of research on the 'failure' of some Occupy camps to get off the ground or to attract support. Factors identified include the differential impact of economic alienation and the diffusion of discontent through elections (Chabanet and Royall, 2015; Chabanet and Lacharet, 2016). In some locations, activists stuck with their existing ideological commitments rather than coming together to camp (Zamponi, 2012), while in others, conversely, campers were isolated from existing associational networks (Uitermark and Nicholls, 2012). Finally, Occupiers are charged with fetishizing camps as ends in themselves rather than appealing to the media or citizenry (Desbos and Royall, 2016; Chabanet and Royall, 2015). Taken together, this work indicates the need to pay attention to weaker, less studied mobilizations, and to both external and internal factors, when thinking about why camps closed - both points strongly endorsed in Davenport's (2015) study of movement death in other contexts - as well as to the importance of place-specific dynamics in shaping the trajectory of mobilization (Roth, 2017)

However, it is problematic to frame the closure of Occupy camps, or the end of movements more generally, as 'failure' or 'death'. Such terminology relies on a view of movements as unified empirical datum, equivalent to persons, with clearly demarcated boundaries. It simplifies the temporality of 
movement struggles, neglecting longer-term efforts at structural and cultural transformation, and privileging more visible protest manifestations of movement struggle over institutionalised or subterranean dimensions. Finally, in line with wider work on movement 'success' and 'failure' (Bosi and Uba, 2009, p. 409), the notion of Occupy failing uneasily combines an ostensibly objective account of the camps with narrow and largely implicit normative criteria for judging them lacking, in this case drawn from the aforementioned Marxist/liberal critique of horizontality. ${ }^{2}$

I suggest that a focus on activist narratives about why camps closed avoids some of these problems. Narrative approaches have become increasingly popular in social movement studies (e.g., Davis, 2002; Mayer, 2014; Polletta and Chen, 2012). In place of Archimedean empirical generalizations or normative judgements about movements, such approaches offer open-ended, interpretive engagement with the ways in which activists make sense of their experiences and articulate competing understandings of collective identity and goals. In this way, narrative approaches fit broadly within a constructivist framework in which movements are conceived as ongoing, contested processes of collective identity construction (e.g., Kavada, 2015). Indeed, Fine argues that the stories participants share with each other are fundamental to what a movement is, as a 'storied community' or 'bundle of narratives' (cited in Davis, 2002, p. 20). Thus movements like Occupy are, in large part, the stories their participants (as well as their opponents and wider publics) tell about them. And activist narratives of movement end merit critical scrutiny as efforts to fix rival understandings of the culmination of the participant experience and of the possibilities for future activism.

This is the stance adopted by Beckwith in her article (2015) on activist 'narratives of defeat'. Concerned with how activists 'make sense of ...losses and give meaning to them' $(2015$, p. 1), Beckwith treats narratives of defeat not only as explanations of movement demobilization, but also as markers of the possibilities for remobilization. Defining such narratives as a sequential ordering of facts and interpretation of their consequences, Beckwith draws on examples from labour organizing to develop the following typology: defeat as a 'learning opportunity', in which activists reflect on their mistakes and how to do things differently when remobilization takes place; defeat as 'defiant survival' in which activists resolve to continue the struggle despite setbacks; defeat as the 'good fight', a moral victory, but political rout; defeat as 'cheating' by the opponent, which occludes activists' own tactical errors and renders remobilization difficult; and lastly defeat as 'betrayal' by elements internal to the movement, in which trust between activists is severed and the movement effectively killed off (summarised 2015, p. 7). Although Beckwith's terminology of 'defeat' can be criticised for implying judgement and a limited sense of temporality in a similar way to the language of 'failure' and 'death', it is possible to apply her framework without the defeat nomenclature. In this vein, the activist account of Occupy emphasizing the repressive role of external forces outlined above offers, in Beckwith's terms, a narrative of camp closure as 'learning opportunity', remaining positive about the prospects for broad mobilizations against austerity after the camps. In contrast, the feminist story I seek to develop here and that emphasises the role of internal dynamics in camp closure, offers a narrative of 'betrayal' in which Occupy is a political dead-end rather than a new beginning. In what follows, I detail the workings of this narrative through an analysis of interview data from Occupy Glasgow.

\section{Methodological Considerations: Feminist Narrative Analysis}

My dataset consists chiefly of the retrospective stories told by seven participants in Occupy Glasgow and/or the campaign to close it down, supplemented by online blogs and interviews with two participants in Occupy Edinburgh. ${ }^{3}$ Semi-structured and lasting between one and a half and three hours apiece, the interviews were conducted in the autumn of 2014. The time-lag clearly allowed interviewees the opportunity to mould a bewildering array of facts into some narrative order (Davis, 2002 , p. 12). However, it also seems to have clouded memories of key details and precipitated 
confusion. Given this, I suggest retrospection is not as important in shaping narrative coherence in what follows as the feminist co-constitution of interview data.

All nine interviewees identified as feminist or (in the case of the two men) feminist allies. This does not reflect my search criteria, but is the result of the self-selection of interviewees in response to emails or social media posts that stated gender inequality was one line of enquiry and linking to my webpage introducing me as a feminist scholar. Feminist identification was reinforced as interviewees connected me to their allies; others refused all effort at contact. Clearly, then, this sample of Occupy campers is not representative. Nonetheless, its unexpectedly feminist character enabled the 'coauthored' character of interviews in the context of mutual feminist identification (e.g., Stern, 2006, p. 186). As Stern elaborates, what interviewees 'included and excluded, as well as the structure of the narrative, was decided in part by who they thought I was, what they wanted me to know, what they wanted me to tell other people' (2006, pp. 185, original emphasis). Shaped by my pre-existing feminist credentials and research questions, then, the interviews became safe spaces for feminist talk about Occupy, with interviewees sharing confidential information and heartfelt responses that would not otherwise have been recorded. As Stern implies, the loss of comparability in this approach is offset by the richness of the resulting data.

I have imposed an additional layer of interpretive order by coding the data in line with the techniques of narrative analysis. First, I looked for the ways in which 'past events are selected and configured into a plot, which portrays them as a meaningful sequence and schematic whole with a beginning, middle and end' (Davis, 2002, pp. 11, emphasis added). I examined key events, their sequencing and any causal relations implied by this, and the overall empirical and affective trajectory. Second, I coded for characterization (Davis, 2002, p. 15; Mayer, 2014, p. chap. 4), seeking to identify key protagonists along with their traits, actions, emotional responses and changes over time. Connectedly, I looked for the ways in which the narrator described his or her own role. Thirdly, I coded for story denouement, or the 'resolution to the action' (Davis, 2002, p. 13). In this regard, I looked for where the protagonists and/or narrator were left at the end of the narrative and the implications for future activism.

My main focus is on personal rather than collective narratives (Davis, 2002, pp. 19-21), the former being told by embodied individuals about their everyday lives and thereby, on a constructivist reading, constituting individual identity and experience rather than relating something already fixed (Mayer, 2014, p. chap. 4). A spotlight upon personal narratives draws attention to embodied activist experience and to heterogeneity of activist interpretation, making visible the fragile and contested character of more collective stories. In this vein, I highlight where the narratives differ as well as where they converge. I begin the final part of the article with my own personal narrative about Occupy Glasgow, serving not only to introduce the camp, but also to situate myself in relation to it.

\section{Case Study: Personal Narratives of Occupy Glasgow}

Occupy Glasgow was established on Saturday 15 October 2011 in George Square, a large area of tarmac and lawn in the centre of the city, near busy shopping streets, adjacent to Council headquarters and dotted with statues and flowerbeds. This large, accessible space has a long history as a protest site. Glasgow is the largest city in Scotland at nearly 600,000 people, and remains scarred by deindustrialisation and levels of poverty that its reorientation to retail and hospitality in the last few decades, and accompanying cultural resurgence and city centre gentrification, have not fundamentally effaced. Thus the city still has significant social problems, including poor housing, health and life expectancy in some areas, and high levels of alcohol consumption and violence (e.g., Donnison and Middleton, 1987; Paterson, 2012). It also has a strong tradition of left-wing politics. Reflecting the social-democratic, anti-austerity orientation of Scotland more generally (Hetheringon, 
2014) and the heritage of organised unionism and radicalism on Clydeside in particular, city residents seemed largely sympathetic to the aims of the camp (e.g., Glasgow Guide, 2011).The Labour-controlled Council was more ambivalent, initial uneasy toleration followed by the pursuit of eviction orders.

I, like many others, was intrigued by the camp. I called in to George Square a couple of times in the first week, on my way to or from work, taking cans of soup and chatting to campers. I also attended a rally on the second Saturday, when speakers from a range of local organizations raged against council policies and the wider status quo. I did not have the time or inclination to engage with the online presence of the camp, and did not stay overnight because the idea of sleeping in a tent in the city where I already lived did not appeal, particularly given its wet, cold weather and hard-drinking reputation. Also, the political purpose of camping remained opaque to me, even if I was not unsympathetic to those who felt compelled to do so. Then I heard the heart-sinking news a few days later of a gang rape at the camp (in the early hours of Wednesday $26^{\text {th }}$ ): yet again a supposedly progressive space had been marred by sexual violence. The women's drumming collective of which I am a member had been asked to play at the upcoming Saturday event, and I tried to draw together a statement to distribute that would make clear our opposition to a culture of violence against women, but my strategy did not gain much support. Reluctantly, I decided to play the gig anyway. We banged our drums in front of huddled tents in a square I remember as near-deserted and scissored with fluttering police tape. Campers agreed to move a few days later, at the start of November, to the large and leafy Kelvingrove Park in the prosperous west end of the city, where they were effectively cut off from the city centre and from media attention, and I did not visit again. In early December, I read online that participants in that camp, and in a smaller breakaway camp at Blythswood Square in the so-called 'financial district' of town, had voluntarily disbanded in the wake of storm damage.

My story of Occupy Glasgow is one in which the details are vague, there are no heroes or villains, my role in the action is peripheral, and the resolution is deeply unsatisfactory. The narratives that are the subject of the rest of this section come from individuals who were much more extensively involved in the politics of the camp and from them emerges a clearer picture of the plotline, protagonists and denouement of Occupy Glasgow.

\section{Plot}

The opening days of Occupy Glasgow were a time of cautious optimism for several interviewees. Not for all - Lindsay ${ }^{4}$, in her early forties at the time of the camp and active in feminist and socialist groups, was critical from the start, attending only 'to keep an eye' on the involvement of anti-semitic groups. Others were more hopeful, in part because the Glasgow camp felt like a piece of something larger, as made clear by Poppy, a young white woman in her mid-20s having her first taste of activism, and for whom participation was 'all connected to this ... bigger movement, about standing up in solidarity'. Or take Bella, a woman of Asian origin in her mid-50s who had disengaged from activism, but who kept an eye on international events: 'the Egyptians came on the scene and then the Tunisians and all the Arabs ... Occupy then came along in America and then London ... [W] hen they started one in Glasgow I thought "this is it!"'. In addition, interviewees were hopeful that a different form of politics was emerging. For Bella, the camp was 'something new that had arisen from the grassroots and local people ... it was all fresh'. This sentiment was echoed by experienced activists like Ryan, a white man in his mid-thirties embedded in left-wing and anti-imperialist networks: 'the main people ... were new faces we'd never seen before. And so that ... made me ... suspend my cynicism... I found I started going regularly.' 
Yet this moment of hope was short-lived. Despite their differences, these narratives of Occupy Glasgow share a structural similarity in their plotting of the story of the camp: the rape in the second week is the pivotal moment, precipitating turmoil and ultimately collapse. This gives to the narratives the quality of a tragedy, in the specific sense of a 'fall' from grace into disaster (Mayer, 2014, pp. 56-57), caused by 'some great error of judgement' on the part of the central protagonist/s (Erskine and Lebow, 2012, pp. 3-4). As such, up until the rape occurred, the collapse of the camp was preventable: after it, the camp was doomed.

In line with the tragedic form, the plotting of narratives is marked by anticipation of the rape, compressing past and future, and tightening the atmosphere of dreadful expectation (e.g., Lacy, 1968). Bella's narrative is the exception here - 'The first inkling I had that something wasn't right was when we found out the news' - but other interviewees repeatedly foreshadow what is to come. Thus Poppy tempers her initial enthusiasm by insisting she was 'shocked' at the rape, but 'not surprised' given 'there had been similar incidences across different Occupy camps ... I'd ... started to think about ... the risks around personal safety'. For Ryan the camp in 'the week leading up to what happened' was being overwhelmed by 'people who were potentially dangerous'. The feeling of being held hostage to the unspooling of terrible events is particularly strong in Elaine's account. A white woman in her early thirties active in anarchist groups, Elaine describes how she originally took on the job of managing online communication, but quickly became the 'safer spaces person'. This was in response to 'loads of instances of aggression', ranging from shouting to violent attacks. On her account, the camp had become a magnet for vulnerable youngsters, especially 'young homeless girls', vulnerable to 'predatory older men with alcohol and drugs'. Despairingly, Elaine recounted how she:

knew something like this was going to happen. That we'd created the perfect conditions for it to happen that week, where women weren't respected... I was shouting at people.... 'What, are you going to wait until someone gets raped? ... and they were like, 'Don't be ridiculous'. And they still wouldn't listen, even after it happened.

Turmoil ensued in the wake of the rape. On Elaine's account, one group issued a statement 'which was horrible. It was basically just blaming the survivor herself': Elaine and her allies - 'men and women alike, we were all crying' - wrote a counter-statement that, however, received little media coverage. Katrina, a white woman in her mid-40s active in several feminist networks participated in the establishment of the Glasgow Women's Activist Forum (GWAF) around this time, to monitor events at the camp. An open meeting was held the subsequent evening at the nearby African Caribbean centre in which Elaine depicts herself as fighting on two fronts, against both the complacency of the dominant voices in the camp and those (largely outside observers, including from GWAF) arguing that the camp should be closed down. This meeting also loomed large for Ryan and Lindsay, both connected to GWAF and withdrawing in disgust when the decision was made to continue, with Ryan declaring, 'I washed my hands of it'.

After these convulsions, the Glasgow camp on all accounts entered a period of decline. Although it moved to Kelvingrove Park for five weeks, and a breakaway camp at Blythswood Square was also established, there are no real plot developments in interviewee narratives. For Bella, Lindsay and Katrina, the story of Occupy Glasgow ends as their own involvement dwindles and, in Katrina's case, as GWAF moved on to other issues before disbanding. Poppy and Ryan visited the camp at Kelvingrove briefly only to have their views about its trajectory confirmed. Elaine and Joanne's stories, in contrast, remain vivid and detailed, as their involvement intensified, yet camp decline is the narrative arc here too, in the form of a downward spiral of violence and conflict. Yet both interviewees managed to find the bleakly funny side, particularly Joanne: 
...the general assemblies broke down ... the Council were having weekly meetings ... [that] were hilarious, nobody really came along.... [And then] of course [there was Harry's Death Star camp [at Blythswood Square] ... it literally crumbled because Bolshevik Peter spat his dummy after he got up in the middle of the night to go for a poo and couldn't find his trainers, got his feet all wet, and they all went home ... we were there twenty-four hours more [then] Hurricane Bawbag got us off the streets.

And so Occupy Glasgow ended - on Joanne's account, with tragedy descending into farce.

\section{Protagonists}

The storm may have delivered the killer blow to Occupy Glasgow, but Joanne and other interviewees indicate it was already doomed. In general, they minimise the role of external or oppositional forces in this trajectory. The public is portrayed as curious and sympathetic. The Council pursuit of eviction after their initial supportiveness 'disappointed' Bella, and relations with them were 'strained' according to Elaine. However, Elaine says the Council were willing to negotiate, to offer 'fencing and toilets and everything to get the camp to move', while its regulatory efforts at Kelvingrove are depicted by Joanne as hilarious rather than threatening. Thus the Council is not the villain of the piece. Neither are the police, universally described as maintaining a low profile.

Instead, Occupiers and their allies are the protagonists of these stories, with multiple factions identified. Thus Elaine describes two 'distinct groups' of the more politically active, crystallizing subsequent to the rape: the first responsible for the initial statement after the rape and for negotiations with the council and the second acting in solidarity with the rape survivor and providing practical support for homeless people. In addition, she points to a group of young hackers, active in both supporting and disrupting online communications; 'a lot of hippies' using the camp 'as a party place'; and 'a group of young homeless guys ... between the ages of 18 and about 25 ' with serious literacy and addiction issues. Interviewees also draw attention to the presence of anti-semitic, conspiracy-theorist groups, and to recurring visits from local left-wing organizations, such as antinuclear activists and the Scottish Socialist Party. After the post-rape meeting, most external supporters seem to have withdrawn - with the exception of GWAF, described by Katrina as connecting with Elaine and Joanne at the camp at this point and pushing alongside them for women's spaces on site, only to retreat in despair a few days later and post a statement online calling for camp closure (2011). The subsequent split into two camps seems reflective of internal polarization around the two chief political factions identified above, with the Blythswood campers characterised as authoritarian and militant, and those at Kelvingrove as 'grass-roots' and 'bottomup' (Joanne).

There are no real 'heroes', but several 'villains' among these protagonists. Bella's account is the exception here, relatively positive about the campers she visited every night for two weeks, their failings characterized as stemming from naivety rather than malicious intent: 'they were like, "Hang on, we don't know about these things, we're not up to date about what rape means." ... But they were young. I would have hoped that that was an education for them'. Other interviewees, however, insist that campers acted knowingly in ways that caused the rape and subsequent decline of the camp. These narrative 'villains' come from two main groups, first, the homeless and drinkand drug- addicted men, some of whom were unpredictable, violent and misogynistic. Elaine, Joanne and Lindsay all talk of 'sexual predators' within this group, while Ryan draws attention to the wider normalization of rape culture: 'she pretty much doesn't get to choose, that was the sentiment'. The second source of 'villains' is the group of dominant, politically-experienced male activists, satirized by Elaine as 'hero-guys': 'it's a thing that you see in left-wing movements ...in Occupy there was loads of guys like that'. These men are accused by Ryan of Machiavellian manipulations behind the 
scenes of ostensibly open meetings, with the complicity of female allies, and of initially paying lipservice to, and then actively resisting, safer spaces and other feminist initiatives. Elaine agrees, explaining how a women's meeting, held on camp in response to the rape and facilitated by a GWAF member, was met with outrage:

we'd asked one of the men to stand at the door of the tent so we could have a women-only space. So that started a big fight outside when some of the men tried to come in ... [W]e said, 'what if we go to the Council and say we want to put a women's camp there [in Kelvingrove]...?' ... but we didn't even get to [make] the proposal, the tension was so high... the guest facilitator ended up leaving in tears ... when the men came in they were just so angry.

The incident described by Elaine finds echoes in Hannah's account of her feminist workshops at Occupy Edinburgh, the second of which she was forced to abandon after being 'met with resistance ... particularly [from] one guy who was really threatening ... The people who called themselves the Love Police ... started circling the tent ... shouting at us in their megaphones to leave in very violent language'. As Hannah's friend lain confirms, these hostile individuals believed feminists were 'trying to divide the movement, you know, whereas actually ... we're just trying to make it more inclusive'. In such ways, politically dominant men in both Glasgow and Edinburgh aggressively contested efforts to extend feminist initiatives into camp life. Finally, the 'hero-guys' in Glasgow are depicted as facilitating dangerous, predatory practices among the homeless men on site. As Elaine puts it, they 'saw themselves as being superior to the homeless ... [but] were backing up the behavior: shouting, rowing, drinking, taking drugs.' This is partly why Elaine finds the statement released to the media in the aftermath of the rape so invidious, because it was 'trying to blame what happened on the homeless people' when their behaviour had been encouraged. With this account, we are reminded of a key element of the tragedic form, that the protagonists' downfall is driven by desire for personal power, and hubris (Erskine and Lebow, 2012, pp. 8-9).

Perhaps surprisingly, interviewees also take on a share of the blame. Although several were subjected to aggression (with Lindsay reporting death threats after posting a blog critical of the camp and Elaine and Joanne facing open hostility on site and a 'barrage' of online abuse), interviewees self-describe as protagonists in the conflict over the camp, rather than victims. Moreover, they convey feelings of responsibility for failing to act more effectively, particularly Elaine: 'we'd invited her and her partner to stay ... Can you imagine ... how you'd feel after that?'. In addition, interviewees faced intractable dilemmas after the rape that brought them into conflict with each other. Katrina indicates GWAF members wanted to help Elaine and Joanne, but not at the cost of their own personal safety; Ryan worries that his opposition to keeping the camp open in the post-rape meeting placed him in the position of arguing against feminist women living on site; and Elaine agonizes retrospectively over her decision to keep fighting to transform the camp from the inside: 'see talking about it now, I'm like "what the fuck was I doing there?" ... [but] when you become that port of call [for homeless young women], it's your responsibility, this is how I felt'. In this way, the narratives resonate also with a reading of tragedy as driven by an 'ethical struggle' within protagonists or between rival moral codes, in which all choices, however well intentioned, lead to suffering (Frost, 2012, p. 24). In effect, while the hubris of dominant men is allocated a determining role in the action, the affective impact of the tragedy is heightened because the feminist narrators faced impossible decisions that brought them into conflict with each other and stymied their response.

\section{Denouement}


How does the story of Occupy Glasgow finish - and with what implications for the legacy of the camp? Poppy hints at positive personal outcomes, because the camp before the rape gave her a 'sense of achievement ... it certainly connected me to my ... path of activism ... in terms of then getting involved in other things'. More broadly, for Bella, it 'woke Glasgow up to the fact that we could be passionate about things not being right and wanting to change it'. In such ways, the camp is depicted as a step on a longer path of political action, even if indirectly, given neither Poppy nor Bella remain involved with the same issues or actors. For other interviewees, however, the balance sheet of the camp was entirely negative. For Elaine, aside from the fact it 'fed and clothed some folk', the camp achieved 'absolutely nothing', while Katrina and Lindsay imply it was actively counterproductive, giving a space to predatory men, exposing women to violence and discrediting left struggle.

Worse still, the camp seems for some participants to have been traumatic, that is, 'so shocking that our everyday expectations about how the world works are severely disrupted' (Edkins, 2002, p. 245). When recounting traumatic events, it can be as if the teller is reliving them, along with associated emotional responses. This helps explain why Elaine broke down in tears several times during her interview, and Ryan paused to gather himself and remarked on how he just relived a lot of that and it was quite horrible'. Moreover, accounts of traumatic experiences can have a 'broken-off' quality (Polletta, 2006, pp. 11-12), evident in interviewee transcripts in silences around the circumstances of the rape itself, and in recurring amnesias. As Hannah declared of Occupy Edinburgh: 'it was really one of the most traumatic experiences I've ever gone through. Which is also maybe why I don't really remember all of it.' For apparently traumatised narrators, the closure of the camps brought with it not only an end to the Occupy movement but also -for the foreseeable future - of activism against austerity. Thus although Ryan maintains his personal involvement in connected issues, he laments that 'all these people coming into things for the first time in their life, none of them are involved in anything now'. Elaine concurs, insisting she herself 'quit' politics after Occupy Glasgow: 'I was just completely burnt out'. On these accounts, then, Occupy Glasgow was not the beginning of something larger than itself, but a political rupture.

\section{Conclusion}

Taken together, the stories discussed here indicate that gendered hierarchies, hostility to feminism and sexual violence were significant factors in the collapse of the Glasgow camp. A couple of interviewees convey more positive experiences and interpretations, but even they emphasise internal problems and minimise the political payoff of the camp. Others expose internal problems in such terrifying detail that it seems remarkable there was only one rape to report and that Occupy Glasgow lasted as long as it did. The reported fracturing of collective identity and traumatizing of individuals surely form part of the explanation of why there has been no documented remobilization of the forces gathered at Occupy Glasgow. These testimonies thus do not support the emergent activist narrative of the end of Occupy and its legacy with which I began. In that narrative, external forces caused the collapse of camps but political energy was rechannelled, in a story of camp closure as 'learning opportunity', to use Beckwith's terminology. In contrast, the interviews reinforce other published feminist activist critiques of Occupy, which insist that - even if weather or the police delivered the final blow - gendered power relations fatally undermined camps and their legacy in many contexts, in a story of camp closure as 'betrayal'.

What does this analysis contribute to published academic work on the Occupy movement? Briefly, it reinforces the argument of the 'failure' literature that smaller, less successful camps are worthy of study for what they reveal about the limitations of Occupy, and that such study should pay attention to internal as well as external factors and to place-specific dynamics. The interviews also underscore the point made by scholars of 'outcomes' that biographical impacts require further attention. Such 
impacts may be negative as well as positive, and may go beyond 'burnout' to produce ruptures in personal commitment that have wider implications for subsequent similar mobilisations. Perhaps also these interviews also point to the need for further research into the ways in which online interactions can militate against, rather than facilitate, more inclusive and sustained mobilization. In more general terms, the analysis here presses Occupy scholarship to take more seriously feminist critiques of the role of gender, and its intersection with other axes of identity and exclusion, in shaping internal dynamics and wider outcomes in the camps (e.g., Talcott and Collins, 2012; McKee Hurwitz and Taylor, 2018; Maiguashca et al., 2016).

The question remains of what this article adds to existing feminist critiques of Occupy. In capturing the vividness of individual interpretations of Occupy Glasgow, I hope to have conveyed a sense of the extent to which gender inequality and its defence scarred the movement in some contexts. Women and feminists faced not just indifference or the blind assumption of privilege, but intense anger, threats and physical violence. In addition, the stories I have told draw attention to the divided response among feminist protagonists, an important reminder of the fact that feminist subjectivity is not unitary as well as of the perennial difficulties of navigating feminist dilemmas in mixed activist contexts. Moreover, the narratives highlight the affective outcomes of experiencing gendered violence and hostility within social movements such as Occupy. We can see how the impact of sexual violence extends far beyond its direct victims, fragmenting the wider activist community and polarising collective identity, as well as producing individual responses strong enough in some cases to trigger the termination of political involvement. In such ways, the article stresses the seriousness of Occupy's internal problems, and the extent of the hard work facing feminists and their allies in any further mobilization against neoliberal austerity.

Although my small dataset and narrative approach cannot yield generalizable causal explanations of why gendered hierarchies, hostility to feminism and sexual violence emerged to such ruinous effect in the camp at Glasgow and elsewhere, it does indicate some lines of future enquiry in this regard. Interviewees draw attention to the gendered consequences of the political ideology and tactics of the Occupy movement, in terms of both ideology and tactics. Thus Bella argues that 'it was almost [an] old style Marxist thing ... when you start introducing things like ... race, gender, you know, these white boys didn't appreciate that', while other interviewee indicate that it was the lack of ideological content that was problematic. As Katrina suggested of the slogan 'we are the $99 \%$ ' 'anybody can come and anyone can project anything they want ... [it] encompasses a whole bunch of subgroupings that ... have interests that are at odds with other ninety-niners' interests'. In parallel, interviewees indicate serious drawbacks with the tactic of setting up protest camps, notably the 'risks around personal safety' (Poppy) and 'micro-aggressions' (Lindsay) that emerge to devastating effect when many of the activists concerned are inexperienced and/or drinking heavily. They also point to the difficulties of camping when faced with other responsibilities: 'Can you imagine... a working class woman who has a family to look after, poor income, no energy ... having time to take part in a camp like that?' (Bella). Bella hints here that any adequate explanation of why gendered exclusions and violences recurred at Occupy needs in addition to consider wider structural factors in society, most obviously the intersection of class, race and gender inequalities, from which social movements are not immune. As Benita Roth insists in her study of the 'death' of ACT UP/LA, 'a feminist intersectional theoretical lens is essential for understanding the dynamics and trajectory' of this and other movement organizations that have 'struggled with maintaining ... coalitional solidarity ... due to intractable social inequalities and increasing heterogeneity within the group' $\left(2017\right.$, p. 5). ${ }^{5}$

I turn finally to consider what we can learn from these interviewee stories about the more general, theoretical question of why movements end. Substantively speaking, they confirm Beckwith's claim that activist 'narratives of defeat' indicate why some movements are unlikely to remobilise, 'even in contexts of favorable political opportunity structures and ample resources' $(2015$, p. 11$)$ as was 
arguably the case in Glasgow, given public sympathy and Council-sponsored relocation. Certainly, it is evident that Beckwith's typology has purchase beyond the labour movement. Occupy activists' stories point to a possible refinement of the typology, I suggest, in that incidences of gendered inequality, sexual violence and hostility to feminism might constitute a distinctive kind of internal betrayal within movements. Of a different and more worrying order from the tactical divergences or withholding of support to which Beckwith refers (p.10), this form of betrayal reflects activist denial, reproduction or violent extension of the intersecting power relations in society mentioned above. In addition, interviewees indicate that those ostensibly on the same side of a tactical conflict within a movement may betray each other, often with the best of intentions. Methodologically speaking, this article has extended Beckwith's approach by focusing attention on personal rather than collective stories. If analysts are to treat a social movement as a 'bundle of narratives', as suggested earlier, then we ought, surely, to be unwrapping the bundle and paying attention to its constituent elements. This means subjecting singular accounts of why a particular movement ended to critical scrutiny and listening carefully to more marginalized voices in particular locations, in order to gain a fuller picture of movement trajectory and legacy.

\section{Notes}

\footnotetext{
${ }^{1}$ These critiques can also be read as one instantiation of the long-standing 'unhappy marriage' of feminism and the left (see, e.g., Alexander et al., 2018) or of ongoing 'gender conflict' in progressive social movements both past (McKee Hurwitz and Taylor, 2018) and present (for parallel dynamics in the so-called Arab Spring, see, e.g., Anonymous, 2013; Al-Ali, 2012).

2 Zamponi's analysis is an exception, defending explicit and reasonable criteria for judgement.

${ }^{3}$ I originally intended to study both camps, but the difficulties I faced accessing Occupy Glasgow interviewees were magnified in the case of Edinburgh, where I had fewer initial contacts.

${ }^{4}$ All names of interviewees, and of other participants named in interviews, are pseudonyms

${ }^{5}$ Additionally, the literature on the difficult relationship of feminism to the Left indicates that the performative and affective dimensions of Occupy camps are part of the explanation of gendered inequalities and violences. See, e.g., Coleman and Bassi (2011) on the tenacity on the Left of regressively gendered codes or 'scripts' of behaviour or Bakan (2012) on the continued 'dissonance' between feminism and other leftist forms of knowing and feeling.
}

\section{Interviews}

Bella, interviewed 22/10/14, Glasgow

Elaine, interviewed 24/10/14, near Glasgow

Hannah, interviewed 30/10/14, Edinburgh

lain, interviewed 30/10/14, Edinburgh

Joanne, interviewed 6/11/14, Glasgow

Katrina, interviewed 6/11/14, Glasgow

Lindsay, interviewed 10/11/14, Glasgow

Poppy, interviewed $1 / 12 / 14$, Glasgow

Ryan, interviewed 4/12/14, Glasgow

\section{References}

Al-Ali, N. (2012). Gendering the Arab Spring. Middle East Journal of Culture and Communication, 5(1), 26-31.

Alexander, K., Eschle, C., Morrison, J., \& Tulbure, M. (2018). 'Feminism in/and the Left: Rethinking the Unhappy Marriage Metaphor'. paper submitted to. Political Studies.

Anonymous. (2012). Occupy-The End of the Affair. Social Movement Studies, 11(3-4), 441-445.

Anonymous. (2013). I Was Raped in Tahrir Square. Retrieved 1 November, 2017 from https://jezebel.com/5990651/i-was-raped-in-tahrir-square. 
Bakan, A. (2012). Marxism, Feminism and Epistemological Dissonance. Socialist Studies, 8(2), 60-84. Beckwith, K. (2015). Narratives of Defeat: Explaining the Effects of Loss in Social Movements. The Journal of Politics, 77(1), 2-13.

Borthwick, M. (2014). Long Live Occupy: How gender justice became part of the Occupy movement. Retrieved 20 August, 2015 from http://rabble.ca/news/2014/12/long-live-occupy-howgender-justice-became-part-occupy-movement.

Bosi, L., Giugni, M., \& Uba, K. (2016). The consequences of social movements: taking stock and looking forward. In K. Uba, L. Bosi \& M. Giugni (Eds.), The Consequences of Social Movements (pp. 3-38). Cambridge: Cambridge University Press.

Bosi, L., \& Uba, K. (2009). Introduction: The Outcomes of Social Movements. Mobilization, 14(4), 409-415.

Castells, M. (2015). Networks of Outrage and Hope: Social Movements in the Internet Age (2nd edition ed.) Cambridge: Polity.

Chabanet, D., \& Lacharet, A. (2016). The Occupy Movement in France: Why Protests have not Taken Off. In M. Ancelovici, P. Dufour \& H. Nez (Eds.), Street Politics in the Age of Austerity (pp. 279-294). Amsterdam: Amsterdam University Press.

Chabanet, D., \& Royall, F. (2015). The 2011 Indignés/Occupy Movements in France and Ireland: An Analysis of the Causes of Weak Mobilisations. Modern \& Contemporary France, 23(3), 327349.

Coleman, L. M., \& Bassi, S. A. (2011). 'Deconstructing Militant Manhood: Masculinities in the Disciplining of (Anti-)globalisation Politics'. International Feminist Journal of Politics, 13(2), 204-224.

Davenport, C. (2015). How Social Movements Die: Repression and Demobilization of the Republic of New Africa Cambridge: Cambridge University Press.

Davis, J. E. (2002). Narrative and Social Movements: The Power of Stories. In J. E. Davis (Ed.), Stories of Change: Narrative and Social Movements (pp. 3-29). Albany, NY: SUNY Press.

Desbos, C., \& Royall, F. (2016). Camps as the Sole Symbolic Expression of Protest: The Difficulties of Occupy in Ireland. In M. Ancelovici, P. Dufour \& H. Nez (Eds.), Street Politics in the Age of Austerity (pp. 253-278). Amsterdam: Amsterdam University Press.

Donnison, D., \& Middleton, A. (1987). Regenerating The Inner City: Glasgow's Experience London: Kegan and Paul.

Doyle, S. (2011). How Occupy's (Non) Power Structure Enables Sexism. Retrieved 20 March, 2014 from http://globalcomment.com/how-occupys-non-power-structure-enables-sexism/.

Edkins, J. (2002). Forget Trauma? Responses to September 11. International Relations, 16(2), 243256.

Ennis, J. W. (2014). Three Years Later, What Has Come of Occupy Wall Street? Retrieved 26 August, 2016 from http://www.huffingtonpost.com/john-wellington-ennis/three-years-later-whatha b 5833682.html.

Erskine, T., \& Lebow, R. N. (2012). Understanding Tragedy and Understanding International Relations. In T. Erskine \& R. N. Lebow (Eds.), Tragedy and International Relations (pp. 1-18). Basingstoke: Palgrave.

Fernández-Savater, A., Flesher Fominaya, C., Carvalho, L., \& et al. (2017). Life after the squares: reflections on the consequences of the Occupy movements. Social Movement Studies, 16(1), 119-151.

Flesher Fominaya, C. (2017). European anti-austerity and pro-democracy protests in the wake of the global financial crisis. Social Movement Studies, 16(1), 1-20.

Frost, M. (2012). Tragedy, Ethics and International Relations. In T. Erskine \& R. N. Lebow (Eds.), Tragedy and International Relations (pp. 21-43). Basingstoke: Palgrave.

Gitlin, T. (2013). Occupy's Predicament: The Moment And The Prospects For The Movement. British Journal of Sociology, 64(1), 3-25. 
Glasgow Guide. (2011). Should Council Evict Occupy Glasgow? Retrieved 14 March, 2014 from http://discuss.glasgowguide.co.uk/index.php?showtopic $=22598 \& s t=0$.

Glasgow Women's Activist Forum. (2011). Open letter from Glasgow Women's Activist Forum to Occupy Glasgow. Retrieved 6 March, 2014 from http://libcom.org/forums/news/openletter-glasgow-womens-activist-forum-occupy-glasgow-01112011.

Graeber, D. (2013). The Democracy Project: A History. A Crisis. A Project. London and New York: Allen Lane.

Halvorsen, S. (2012). Beyond the Network? Occupy London and the Global Movement. Social Movement Studies, 11(3-4), 427-433.

Halvorsen, S. (2015). Taking Space: Moments of Rupture and Everyday Life in Occupy London. Antipode, 47(2), 401-417.

Hardikar, A. (2012). The Value of a Safe Space: One WOC's experience with harassment at Occupy Wall Street. Retrieved 6 March 2014 from http://infrontandcenter.wordpress.com/2011/10/13/the-value-of-a-safe-space/.

Hetheringon, P. (2014). Scotland is already a country apart, and a social democratic one. Retrieved 14 March, 2014 from http://www.theguardian.com/society/2014/mar/11/scotland-countryapart-social-democratic-independence.

Hogue, I. (2012). Occupy Is Dead! Long Live Occupy! Nation, 294(14), 14-14.

Kavada, A. (2015). Creating the collective: social media, the Occupy Movement and its constitution as a collective actor. Information, Communication \& Society, 18(8), 872-886.

Kriesi, H. (2016). Mobilization of Protest in the Age of Austerity. In M. Ancelovici, P. Dufour \& H. Nez (Eds.), Street Politics in the Age of Austerity (pp. 67-90). Amsterdam: Amsterdam University Press.

Lacy, D. L. (1968). Anticipation and Foreboding in Shakespearean Drama (PhD. Louisiana State University Historical Dissertations and Theses.

Maharawal, M. M. (2011). So Real it Hurts: Notes on Occupy Wall Street. Retrieved 13 October, 2017 from http://www.leftturn.org/so-real-it-hurts-notes-occupy-wall-street.

Maiguashca, B., Dean, J., \& Keith, D. (2016). Pulling together in a crisis? Anarchism, feminism and the limits of left-wing convergence in austerity Britain. Capital \& Class, 40(1), 37-57.

Manilov, M. (2013). Occupy at One Year: Growing the Roots of a Movement. The Sociological Quarterly, 54(2), 206-213.

Mayer, F. W. (2014). Narrative Politics: Stories and Collective Action Oxford: Oxford University Press.

McAlpine, M. (2011). De-Occupy Glasgow. Retrieved 6 March, 2014 from http://www.2ndcouncilhouse.co.uk/blog/2011/10/27/de-occupy-glasgow/.

McKee Hurwitz, H., \& Taylor, V. (2018). Women Occupying Wall Street: Gender Conflict and Feminist Mobilization. In H. J. McCammon \& L. A. Banaszak (Eds.), 100 Years of the Nineteenth Amendment: An Appraisal of Women's Political Activism (pp. 334-355). Oxford: Oxford University Press.

McKeown, M. (2011). Rape and the Occupy Movement. Retrieved 20 March, 2014 from http://www.newleftproject.org/index.php/site/article comments/rape and the occupy $\mathrm{m}$ ovement.

Paterson, S. (2012). Scottish Council Election: Issues Facing Glasgow. Retrieved 14 March, 2014 from http://www.bbc.co.uk/news/uk-scotland-scotland-politics-17669062.

Penny, L. (2016, 17 September). Occupy Wall Street, five years on: fire in the dustbin of history. New Statesman. Retrieved from http://www.newstatesman.com/world/2016/09/occupy-wallstreet-five-years-fire-dustbin-history

Piven, F. F. (2014). Interdependent power: Strategizing for the Occupy Movement. Current Sociology, 62(2), 223-231.

Polletta, F. (2006). It Was Like a Fever: Storytelling in Protest and Politics Chicago: Chicago University Press. 
Polletta, F., \& Chen, P. C. B. (2012). Narrative and Social Movements. In J. C. Alexander, R. Jacobs \& P. Smith (Eds.), The Oxford Handbook of Cultural Sociology (pp. 487-506). Oxford: Oxford University Press.

Pollitt, K. (2012). Women: Occupy the Left. Nation, 294(21). Retrieved May.

Roberts, A. (2012). Why the Occupy Movement Failed. Public Administration Review, 72(5), 754-762.

Roth, B. (2017). The Life and Death of ACT UP/LA: Anti-AIDS Activism in Los Angeles from the 1980s to the 2000s Cambridge: Cambridge University Press.

Roth, S., Saunders, C., \& Olcese, C. (2014). Occupy as a Free Space - Mobilization Processes and Outcomes. Sociological Research Online, 19(1), 1.

Selzer, S. (2011). Where Are the Women at Occupy Wall Street? Everywhere-and They're Not Going Away Retrieved 6 March, 2014 from http://www.thenation.com/article/164197/where-arewomen-occupy-wall-street-everywhere-and-theyre-not-going-away.

Sotirakopoulos, N. (2016). The Rise of Lifestyle Activism: From New Left to Occupy Basingstoke: Palgrave Macmillan.

Stern, M. (2006). Racism, sexism, classism, and much more: reading security-identity in marginalized sites. In B. A. Ackerly, M. Stern \& J. True (Eds.), Feminist Methodologies for International Relations (pp. 174-197). Cambridge: Cambridge University Press.

Talcott, M., \& Collins, D. (2012). Building a Complex and Emancipatory Unity: Documenting Decolonial Feminist Interventions within the Occupy Movement. Feminist Studies, 38, 485506.

Tufekci, Z. (2017). Twitter and Tear Gas: The Power and Fragility of Networked Protest New Haven Yale University Press.

Uitermark, J., \& Nicholls, W. (2012). How Local Networks Shape a Global Movement: Comparing Occupy in Amsterdam and Los Angeles. Social Movement Studies, 11(3-4), 295-301.

Zamponi, L. (2012). 'Why don't Italians Occupy?' Hypotheses on a Failed Mobilisation. Social Movement Studies, 11(3-4), 416-426. 